\title{
The Politics of Government-Funded Research: Notes from the Experience of the Candidate Emergence Study*
}

\author{
L. Sandy Maisel, Colby College \\ Walter J. Stone, University of Colorado, Boulder
}

\begin{abstract}
In the summer and fall of 1997, we became embroiled in a controversy surrounding our study of potential candidates for the U.S. House of Representatives, entitled the Candidate Emergence Study (CES). The study is funded under a grant from the Political Science Program of the National Science Foundation. The focus of the study is on understanding the decision-making process of potential candidates-those who decide to run, and especially those who decide not to run.
\end{abstract}

\section{Design of the Candidate Emergence Study}

The design of our study involved two surveys administered by mail in 200 randomly selected U.S. House districts. The first survey was of approximately 20 informants in each district, chosen because they were likely to be knowledgeable about the politics of their districts. Our goal was to identify 10 Democrats and 10 Republicans in each sample constituency, most of whom were national convention delegates. We asked informants to name up to four individuals in their district who would be strong candidates for the House, whether or not those individuals had ever been mentioned as potential candidates, and whether or not they had shown any interest in running. Informants were also asked to provide information about their district and to rate the incumbent and the potential candidates they named on a variety of characteristics.

The second survey was of potential candidates named by the informants and of state legislators whose constituencies overlap our sample of congressional districts. We asked potential candidates about their ambitions to hold public office, their likelihood of running for the House in 1998 or in the foreseeable future, their perceptions of the incumbent House member and the House district, their perceptions of their chances of winning if they should decide to run, and a variety of other topics in order to measure their perceptions of the opportunities, costs, and benefits associated with pursuing a seat in the House.

When approaching our respondents in both phases of the survey, we explained that ours was an academic study, that we had no purpose other than to understand the process of decision making that potential candidates go through as they consider whether or not to
L. Sandy Maisel is the William R. Kenan, Jr. Professor of Government at Colby College, Waterville, Maine 04901. During the 1998-99 academic year, he is on sabbatical leave. In the fall, he is serving as the Philippine Centennial Distinguished Fulbright Lecturer in Manila. Commencing in January, he will be a guest scholar at the Brookings Institution. He can be contacted via email at Ismaisel@colby.edu throughout the year.
Walter Stone is professor of political science at the University of Colorado, Campus Box 333, Boulder, CO 80309. During the 1998-99 academic year, he is a visiting scholar at the Hoover Institution, and visiting professor in the Department of Political Science, Stanford University, 450 Serra Mall, Building 160, Stanford, CA 94305-2044. He can be reached at Walter.Stone@colorado.edu. run for office. We guaranteed all respondents that their identity would be kept confidential, and that their responses to our survey would be anonymous and reported only in statistical summaries of the data.

\section{The Controversy}

The first stage of the controversy surrounding the CES took place during the summer of 1997, shortly after we mailed approach letters explaining the study to informant respondents. It began when several members of Congress attacked the study. The press picked up the story, and an amendment to the NSF appropriations bill was passed on the floor of the House to express members' dissatisfaction with NSF for funding the study. The second stage began in October 1997, when a General Accounting Office (GAO) investigation of the CES was launched. Because different issues are raised, we describe the events surrounding each stage of the controversy separately before discussing the broad issues this affair raises for the social sciences.

\section{The Summer Phase}

As soon as we sent our advance letter to our informant sample in June of 1997, we began to receive phone calls from congressional offices asking about the study. By the end of the summer, we had heard from approximately 20 congressional offices. Most callers assumed that we were only surveying in their representative's district, and some 
thought that we were trying to find challengers to run against their boss. When we assured them that we were political science professors, that we were conducting our study in 200 randomly selected districts, that we were contacting equal numbers of activists in both political parties, and that we had no interest in stimulating anyone to run, virtually all callers were completely mollified. Some even wished us luck in our study and expressed an interest in seeing our results when they became available.

\section{Representative Clay's Response to the CES}

One member's staffers were not persuaded. After we had several telephone conversations with his staff, Representative Bill Clay (DMO), issued a press release on June 17, 1997, entitled "Federal Dollars Used to Recruit Congressional Candidates." In the six-paragraph re- lease, Mr. Clay called for suspending the study, expressing "outrage ... that our tax dollars are being wasted on a study to find candidates to run for office." Clay asserted that "there is never any shortage of good and qualified people who feel they could serve in Congress" and that Maisel and Stone "have refused to answer inquiries by congressional committee staff about the details of this socalled scientific study." He went on to say, "I remember the federal government spending taxpayer dollars to fund the Tuskegee experiment in the interest of science. We have learned that only full, thorough, and immediate disclosure of the facts can reveal whether a study is scientific." In a letter dated June 24, 1997, Clay and three other House members requested an investigation of our project by the Inspector General of the National Science Foundation and by the General Accounting Office. Following Congressman
Clay's press release, the press was on to the story, our phones rang non-stop, and stories and editorials appeared in newspapers nationwide.

In our conversations with Congressman Clay's staff, we answered every question they asked, except one: They requested the identity of the congressional districts in our sample so they could "verify" that the sample was randomly selected. The question of whether our districts were randomly selected was reasonable, since random selection would have been inconsistent with a partisan political agenda targeting specific members of Congress and recruiting individuals to run against them. As we explained to Representative Clay's aides, we kept the identity of our districts confidential because releasing them would be tantamount to identifying our respondents in some districts, where we took a census of all eligible individuals in the informant stage of the

\section{APSA Council Reaffirms Freedom and Integrity of Research}

At its September meeting, the APSA Council reaffirmed the Association's current guidelines regarding the responsibilities of scholars and funding sources toward the integrity and freedom of social science research in a democratic society. The Council's actions were precipitated by the controversy surrounding Representative Bill Clay's (D-MO) unsubstantiated allegations challenging the scientific integrity and objectivity of the Candidate Emergence Study, carried out in 1997 by political scientists Sandy Maisel of Colby College and Walt Stone of the University of Colorado. Maisel and Stone give an account of their unfortunate saga in the following essay. The Candidate Emergence Study was a peer-reviewed, scientific investigation, funded by the Political Science Program of the National Science Foundation. Informants chosen from a random, representative sample of congressional districts were asked to identify potential candidates. The potential candidates were then surveyed by mail. Upon learning of the study, several members of Congress questioned the study's objectivity, leading the House of Representatives to approve a reduction in NSF appropriations as a show of their displeasure with the science agency for funding this type of political science research. The provision was dropped in conference.

The APSA Council, with the assistance of the Committee on Professional Ethics, Rights and Freedoms, chaired by Matthew Moen, and the chairs of the Committee on Education and Professional Development and the Research Support Advisory Committee, reaffirmed APSA's guidelines on the integrity of political science research. The guidelines were first articulated in the "Bernstein Report" of 1967. The Council's statement and additions to the Association's Guide to Professional Ethics are reproduced below.

$$
\begin{aligned}
& \frac{\text { A Statement of the American Political }}{\text { Science Association }} \\
& \text { "FREEDOM AND INTEGRITY OF RESEARCH: } \\
& \text { THE RESPONSIBILITIES OF SCHOLARS AND } \\
& \text { FUNDING SOURCES IN A DEMOCRATIC SOCIETY" }
\end{aligned}
$$

Preface

Political scientists have ongoing concerns about the relationship between research and funding, especially in the area of confidentiality of sources. Scholars must be able to conduct research in our democratic sociely, free from pressure to disclose properly contidential information.

In 1967, the American Political Science Association created a Committee on Professional Standards and Responsibilities, which issued a report providing guidelines for professional conduct by political scientists. One element of that report warned scholars of possible complications if they accepted funding from sources lacking a commitment to dispassionate scholarship; the burden was placed primarily upon the scholar rather than the funding source. Yet, those who fund research- particularly public institutions and agencies - also have professional obligations. They need to recognize the vital contribution that political scientists make by studying democratic institutions, and they should not impede legitimate scholarly inquiry. 
study. In our proposal and elsewhere, we had already fully described the procedures we followed to identify the population of district informants. If we disclosed our districts, it would have been a simple matter to track these people down in many districts, and their anonymity as respondents to our survey would have been compromised.

Because of the legitimacy of the question about random selection, however, we prepared a detailed analysis of the districts in our sample, comparing them with districts not included in the sample. We sent a copy of this memo to Congressman Clay and to every Hill office that had raised questions about the study. On a wide range of indicators, there were no significant differences between the sample districts and the non-sample districts, which is exactly what is expected of a random sample.
With the controversy mounting, we welcomed the opportunity to answer Clay's charges through the Inspector General's (IG) investigation of the CES. The Office of the Inspector General was created to investigate charges of scientific fraud and programmatic malfeasance. Thus, its officers were ideally suited to determine whether we were acting fraudulently by recruiting candidates with NSF money, as Clay continued to insist.

We hoped that the Inspector General's investigation would lay to rest the concerns expressed by Congressman Clay's office. We cooperated fully with the IG in every aspect of their scrutiny of our project. Their investigators interviewed us, the program officers at NSF, and a variety of others involved in the review and award of the grant. They reviewed the design of the research to be certain it conformed with what we proposed, and they examined the letters, questionnaires, and other documents we used in contacting our respondents. As requested by Congressman Clay and his colleagues, the IG filed its report on July 9,1997 , in advance of the floor debate on the 1998 NSF appropriations bill. After describing the peerreview process used by the Political Science Program to award the grant and the academic nature of the questions the proposal was designed to answer, the report concluded: "The research being conducted in the Candidate Emergence Study is fully consistent with the research that was proposed to NSF and that the NSF chose to fund. The cover letter accompanying the survey questionnaire is also consistent with the purposes of the study that Dr. Stone and Dr. Maisel proposed" (National Science Foundation 1997, 6).

\section{Reaffirming Current Guidelines}

The Guide to Professional Ethics in Political Science provides a clear and forceful statement about a researcher's obligation to maintain confidentiality of sources, balanced with restraint in making claims of confidentiality and with disclosure of nonconfidential sources (Section A.6). These principles endure and deserve reiteration.

The Guide to Professional Ethics in Political Science also notes that "financial sponsors of research should avoid actions that would call into question the integrity of American academic institutions as centers of independent teaching and research" (Section A.1.3); it mentions that "the grantor shall not impose any restriction on or require any clearance of research methods, procedures, or content" (Section A.1.5). These provisions are worth restating to remind all funding sources that they should refrain from interfering with legitimate scholarly inquiry, even if a research product is unsettling to its sponsors. Scholars and funding sources alike must recognize and defend these principles of research, particularly given the substantial reliance of the academy on external sources of funding.

The American Political Science Association reaffirms its enduring commitment to confidentiality of sources and to uncompromised and independent scholarly inquiry.

\section{New Language}

Beyond reaffirmation of important principles already in place, the following revisions to the Guide to Professional Ethics in Political Science are hereby adopted by the APSA Council. These revisions will be distributed throughout the political science community, and, with the assistance of the Consortium of Social Science Associations, to the broader community of social and behavioral scientists.
A.1.8. Members of public institutions or agencies should not interfere with disinterested scholarly investigation of their actions, processes, or functions. Public institutions should recognize the value of scholarship and acknowledge that interference with bona fide scholarship is contrary to the core values on which our democratic institutions are predicated.

A.1.9. Governmental and nongovernmental officials and agencies that fund scholarly research should understand that scholars have a professional obligation to protect the identity of confidential sources of information or data that is developed in the course of researching institutions, agencies, or persons. Funding entities should help scholars fulfill their obligations, not impede them.

\section{Council Supports Maisel and Stone}

In addition to promulgating these research guidelines, the APSA Council formally placed itself behind Maisel and Stone. It was the unanimous sense of the Council that attempts by public officials to interfere in the Candidate Emergence Study was a serious breech of the guidelines governing the freedom and integrity of political science research. The Council also expressed its confidence in the project's principal investigators, Sandy Maisel and Walt Stone, and support for their efforts to uphold the research guidelines. 


\section{The Debate on the Floor}

When the $\$ 2,537,700,000 \mathrm{NSF}$ appropriations bill came to the House floor on July 17, 1997, Mr. Clay, and Representative Jerry Lewis (R-CA), chair of the relevant appropriations subcommittee, came prepared with an amendment to delete $\$ 174,000$ from the NSF appropriation, the exact amount of our grant. ${ }^{1}$ They were joined in the debate by two other supporters, Louis Stokes (D-OH) and George Brown (D-CA). In roughly 20 minutes of debate on this amendment, these four congressmen spoke in support of docking the NSF appropriation the amount it had used to fund the CES. Representative Clay called the study "an affront to every member of this Congress." He went on to say, "Because these two professors start with the premise that we are not getting the best qualified people to serve in Congress ... they are saying they are going to take $\$ 200,000$ of taxpayers' money, go out and find the best qualified people to run for Congress and then encourage them to do just that." Representative Brown, rose in support of the amendment, saying: "I hope that [the amendment] will convey the message to the National Science Foundation that while we support good research, including good social science research, we think there should be some good judgment displayed over there in setting the groundwork for such items that may turn out to be controversial with the members of Congress."

Throughout the debate, no supporter of the amendment mentioned the IG investigation that had been requested and provided before the appropriations debate. Instead, Representative Lewis reported on his conversations with "absolutely the highest level within the National Science Foundation" that there is "embarrassment" and that "not just the results but the format of the study that came from this grant is considerably different than some thought it would be."

Our one defender in the debate, Representative Barney Frank (D-MA), argued that the House ought not second-guess the peer- review process at NSF: "The notion that this body should set itself up as a kind of appellate research council is, I think, one of the worst I have heard in a long time.... I do not think that we make a very good set of academic censors" (Congressional Record 1997, H5322-H5325, H5328). ${ }^{2}$

While we were distressed that Congressman Clay and his colleagues ignored the Inspector General's conclusion about our study and implied, without evidence, that the NSF regretted funding our project, we hoped that this largely symbolic effort by those opposed to our study would end the controversy. In that hope, we were thoroughly disappointed.

\section{The GAO Investigation in the Fall}

In October 1997, we were contacted by investigators for the General Accounting Office. They informed us that they were moving ahead on Congressman Clay's request for an investigation. As part of their inquiry into the CES, they sent us a letter posing more than 30 questions about the details of our study, including the sampling methodology, response rates, materials mailed to respondents, and procedures and safeguards we were following to protect the confidentiality and anonymity of our respondents. Literally on the eve of the deadline for submitting our answers, after our report was written and ready to be mailed, we received an email from the lead investigator asking for the following additional information: "(2) the list of 200 Congressional districts selected ... (3) a list of names and addresses of the informants, along with certain characteristics of the informants ... and, (4) a list of the informants who actually responded and provided names of emergent candidates."

We responded to the GAO investigators that we could not comply with a request to release the identity of our respondents and we contacted attorneys for Colby College and the University of Colorado. Intense negotiations began with the
GAO and the General Counsel of the National Science Foundation. The GAO wanted to conduct on-site investigations that would include examining our procedures for protecting the confidentiality of our respondents. We agreed to cooperate with an on-site investigation, but we continued to refuse to provide the identities of our respondents. The GAO countered by offering to examine the data on-site only, not to take notes, and not to take away any information from our files. With these guarantees, we agreed in principle to identify the districts involved in the study to the GAO investigators. This information was pertinent to their investigation of whether the sample was randomly drawn. We were also prepared to replicate all analysis carried out for the random sample memo and to conduct any further analysis requested by the $\mathrm{GAO}$ to verify the random nature of the sample.

We stress that we made this concession to identify the districts because we were guaranteed that no data would be removed from the University of Colorado, where the files were held, and that the GAO investigators would not reveal the identity of any districts to members of Congress or to anyone else.

Moreover, given these restrictions, we felt that identifying the districts would verify that the CES had no political motivation and was carried out in a way consistent with the design spelled out in our original proposal.

As it happened, the GAO never made its on-site investigation, because we continued our refusal to comply with the third and fourth requests listed above. We felt that releasing the identity and characteristics of our respondents would be a direct violation of our commitment to protect the confidential and anonymous nature of their responses. The GAO's response was to threaten to subpoena the information. Their attorneys claimed that the enabling legislation that created NSF gives the Comptroller General the right to privileged information that is pertinent to an investigation of the sort they were conducting. We claimed that we were bound to 
protect respondent anonymity and confidentiality by the moral force of our commitment to the participants in our study, and by the professional and legal obligations we incurred under the human subjects law. In addition, we argued that the information was not pertinent to the investigation. Having established that the districts were randomly selected, and having established that our procedures called for contacting political activists in the districts, what, from their point of view, was to be gained by verifying that that was what we did? Indeed, even had we been pursuing a political agenda, as Congressman Clay charged, who else other than political activists would we have contacted? ${ }^{3}$

At this point, we were prepared to fight a congressional subpoena with the support of Colby College and the University of Colorado. Attorneys for the two schools devoted a considerable amount of time and effort to negotiating with the GAO and General Counsel at NSF. Everyone on all sides agreed that there was absolutely no precedent for a GAO investigation of a single study on grounds similar to those motivating the inquiry into the CES, nor was there any precedent for the GAO's request for the identity of respondents in a social science research project. Because of our refusal to release the identity of our respondents, we were at a stand-off in December. No formal agreement was ever reached on how an on-site investigation would be conducted, and no such ever investigation took place.

Because we did not relish the idea of fighting a subpoena, we turned to our friends on the Hill and elsewhere. Congressman Frank was extremely helpful in discussing the matter with Representative Clay on a number of occasions. Bernard Rapoport interceded on our behalf with former House speaker Jim Wright and Congressman Frost, both of whom also contacted Clay. Eventually, Clay was persuaded to ask the GAO to halt the negotiations with us and to wrap up their report. On March 16, 1998, the GAO filed its report, in which it blandly concluded that "The two grant proposals were submitted, reviewed, and processed according to NSF's grant policies and procedures." While the GAO investigators indicated that they "did not examine the merit of the research projects," they did find that the Political Science Program is within NSF's mission, and that appropriate grant award procedures were followed in making the grants to Colby College and the University of Colorado (General Accounting Office 1998).

\section{Issues Raised by the Investigation of The CES}

Although the investigation had obvious effects on us, the broader issues it raises are important to social scientists engaged in research. The first issue raised relates to an overt attempt by a few members of Congress to deter the systematic study of an important part of the process of representation in the United States. As much as political scientists may value basic research on American democracy, it is clear that some members of Congress may not share these values. The fundamental problem raised by this controversy is that the agency commissioned to support basic empirical research on American democracy (among other things) is funded by the institution under study. If members of Congress do not wish to be studied in particular ways by government-sponsored researchers, they have the power to communicate that preference forcefully. In this context, the implication is that the Political Science Program at NSF put its existence at risk by funding the Candidate Emergence Study, thereby jeopardizing the many projects it might fund in the future. There is also the risk that future NSF officials will be deterred from funding projects they believe will touch off the sorts of reactions we experienced, or that researchers themselves will refrain from preparing and submitting proposals on these topics.

Everyone familiar with this case has heard rumors that the Political Science Program's very existence was jeopardized by this controversy.
One does not need rumors, however, to establish that the critics of the CES in Congress meant, in no uncertain terms, to send a message to the NSF that it had made a grievous mistake in funding the study. The study was characterized as an "affront," a "travesty," and an "embarrassment." No one on the floor challenged Congressman Frank's portrayal of the Lewis Amendment as an attempt to "censor" academic work, because that is exactly what the amendment backers were trying to do. Although Congressman Clay and his colleagues specifically required the IG to file its report before the floor debate, neither he nor any of the other members who attacked the study referred to the report. Indeed, they made a number of statements on the floor that were directly refuted by the IG report. That they ignored the report indicates that the entire purpose of the investigation was to harass us for carrying out the study, and to deter future scholars from conducting similar research.

In short, this was a clear attempt to punish the NSF for funding a study that had gone through the normal peer-review process, and to discourage it from funding future studies of this sort. The point was to influence the social science research agenda by discouraging NSF-sponsored researchers from studying Congress. Of course, members of Congress are entitled to hold the opinion that the Congress ought not be subjected to study in this way, but it does seem important for political scientists to argue the opposing view. Moreover, it is our collective responsibility to defend the rights of scholars to conduct legitimate socialscientific inquiry without government harassment and interference.

That said, we also acknowledge that government funding agencies and even individual scholars are broadly accountable to political decisionmakers. Legitimate questions can be raised about the public purposes that are served by social science research and whether continued support is in the public interest. Representatives of our discipline must be prepared to explain the importance of political science re- 
search to a sometimes skeptical public, and to justify the need for the modest public support we receive for basic research in the discipline. At the same time, individual scholars who embark on field research must be ready to answer questions about what they are doing and why. Much of what political scientists do is not understood very well by the public or by the press. One of the distressing byproducts of the CES controversy was that many of our defenders in the press accepted the premise of our critics that we were trying to recruit better members of Congress. They thought that this was a splendid project and a marvelous use of federal research funds!

One possibility, however remote, is that our research project actually had something of the effect that Clay feared, that by carrying out the study we unwittingly stimulated some people to run for Congress who otherwise would not have entered the race. We think it is unlikely that individuals would make a decision with enormous consequences for themselves, their careers, and their families because they were contacted by two political science professors and asked to reflect on their political ambitions. But what if we are wrong in that opinion? What if our study did stimulate people to run or to consider running? ${ }^{4}$ Even if there were a very strong effect whereby potential candidates identified through the CES were stimulated to run in 1998 or in later years, it would not follow that we had a political agenda in conducting the study. The sample was randomly selected and we contacted equal numbers of Democratic and Republican activists for help in identifying potential candidates. Thus, if the study did change the candidate pool, it did so in ways that are unlikely to provide disproportionate aid to one party over another, or to reflect our own political preferences. Despite our confidence on this score, it is sobering to consider the possibility that one's research is affecting the world under study, perhaps in ways that are completely unanticipated. This is an issue that crops up regularly in other fields, and it may be time for political scientists to revisit its implications for the ethics of our research activities. ${ }^{5}$

Another issue raised by this affair relates to the confidentiality and anonymity of respondents. In making the usual guarantees to our respondents that we would protect the confidentiality of their participation in the study, we were following normal practice under human subjects guidelines. Indeed, had we not been willing to make those guarantees, the funding for our study would not have been granted. It is more than a small irony that the government was threatening to force us to violate the commitment it set as a condition for funding the research in the first place.

Another irony of our experience is that a significant number of the questions posed by the GAO asked us to describe the procedures we were following to protect the identity of our respondents and the confidentiality of their responses. Despite our attorneys' argument that the human subjects guidelines were in direct conflict with the legislation that gives the GAO the right to subpoena confidential information "pertinent" to an investigation, and despite everyone's recognition that their demand for the identity of our respondents was without precedent, the GAO investigators and attorneys never conceded that their demand was inappropriate.

We are very grateful to the APSA Council for its reaffirmation of the importance of basic research on democratic institutions and for its revisions to the Guide to Professional Ethics in Political Science stimulated by our experience. The Council's strong statements opposing government interference in scholarly research and supporting researchers' professional obligations to protect the confidentiality of survey respondents hit on exactly the issues that we see being raised by this episode. By endorsing these principles, the Council has taken an important step toward rectifying the dangerous precedents set by the House in the summer and by the GAO investigation in the fall.

The APSA should consider communicating its strong stand deploring government interference and protecting respondent confidentiality to its sister associations in the social and behavioral sciences. We also believe that the APSA and other scientific organizations should stand ready to defend individual scholars faced with an attack that threatens basic principles of scientific practice. Had the threatened GAO subpoena of our informants' identity been issued, it would have had a potentially chilling effect on social science research in many disciplines. We hope that our experience will alert all relevant scholarly associations to the risks that can jeopardize the work of social scientists. Perhaps some good can emerge from this sorry episode if politicians, government agencies, and academic researchers can approach a shared understanding of the importance of the standards articulated by the APSA in the Council's important resolutions.

\section{Notes}

\footnotetext{
* Thanks to Ann Cassidy-Stone, Cherie Maestas, and Ron Rapoport for comments on an earlier draft. We are grateful beyond measure to the countless friends and associates who supported us throughout the events described in this essay.

1. Actually, the amount of our grant was
}

$\$ 175,000$. Perhaps because there were in fact two grants-one to Colby College and one to the University of Colorado-the exact amount of our grant was confused in a number of different places.

2. Other Members defended us in other ways, including Representative David Price
(D-NC), who, with Mr. Frank, wrote a letter to Dr. Neal Lane, Director of NSF, indicating their opposition to congressional interference. Martin Frost (D-TX), chair of the Democratic Congressional Campaign Committee, wrote a letter to all Democratic members explaining that our project was a 
legitimate research project with no political purpose.

3. As many of our colleagues are aware, we also contacted political scientists as part of our informant sample in districts that contained a college or university that employed a specialist in American politics. Everyone was well aware of this exception to the political

\section{References}

Congressional Record. 1997. 105th Cong., 1 st sess., vol. 143, pt. 1245 .

General Accounting Office. 1998. "Federal Research: Two Political Science Grants Awarded by the National Science activist criterion because that was spelled out in the original proposal and in our responses to GAO questions about the informant sample.

4. Because we have a random sample, we can treat our design as an experiment and assess its effect on the pool of candidates in the sample districts compared with districts not included in the study. At this writing, we have not made any comparisons of this sort, but we will report our findings related to this possibility in future published work.

5. Should funding agencies, for example, consider the real-world implications that may result as byproducts of the research they support?

What are the rights and obligations of individual scholars with respect to these issues?
Foundation." Letter to the Honorable William L. Clay and Bennie G. Thompson from Susan D. Kladiva, Associate

Director, Energy, Resources and Science Issues. General Accounting Office of the
United States, Document B-278177, March 16.

National Science Foundation. Office of Inspector General. 1997. Report No. 97 3200 , July 9 . 